九州大学学術情報リポジトリ

Kyushu University Institutional Repository

Incorporation of Inorganic Nitrogen into Protein Fraction in Tomato Plants Grown with Ammonium and Nitrate as Nitrogen Sources

Ikeda, Motoki

Laboratory of Plant Nutrition and Soil Fertility, Faculty of Agriculture, Kyushu University

Yamada, Yoshio

Laboratory of Plant Nutrition and Soil Fertility, Faculty of Agriculture, Kyushu University

https://doi.org/10.5109/23662

出版情報：九州大学大学院農学研究院紀要. 22 (3)，pp.161-168，1978-07. Kyushu University バージョン：

権利関係 : 
J. Fac. Agr.. Kyushu Univ., 22, 161-168 (1978)

\title{
Incorporation of Inorganic Nitrogen into Protein Fraction in Tomato Plants Grown with Ammonium and Nitrate as Nitrogen Sources
}

\author{
Motoki Ikeda and Yoshio Yamada \\ Laboratory of Plant Nutrition and Soil Fertility, Faculty of Agriculture, \\ Kyushu University 46-02, Fukuoka 812
}

(Received November 28, 1977)

\begin{abstract}
Incorporation of ${ }^{15} \mathrm{NH}_{4}-\mathrm{N}$ and ${ }^{15} \mathrm{NO}_{3}-\mathrm{N}$ into an insoluble (protein) fraction was examined in the tomato plants previously grown with $\mathrm{NH},-\mathrm{N}$ and $\mathrm{NO},-\mathrm{N}$ for 6 days. Each tissue of the ammonium-plant except a stem and roots had a higher total nitrogen content than that of the nitrate-plant. An insoluble nitrogen content was higher in all the tissues of the ammonium-plant than in those of the nitrate-plant. The proportion of the protein nitrogen content to the total nitrogen content was also higher in all the tissues of the ammonium-plant. A considerable part of nitrogen absorbed during ${ }^{15} \mathrm{~N}$ application $\left({ }^{15} \mathrm{~N}\right)$ remained in the roots of the ammonium-plant as compared with the nitrate-plant. On the other hand, a larger amount of ${ }^{15} \mathrm{~N}$ accumulated in a stem of the nitrate-plant. The proportion of protein ${ }^{-15} \mathrm{~N}$ to total ${ }^{15} \mathrm{~N}$ was higher in all the tissues of the ammonium-plant than in the nitrate-plant. These results suggest that even after 6 days' treatment with $100 \mathrm{ppm}$ of $\mathrm{NH},-\mathrm{N}$, absorbed ammonium nitrogen was utilized for the protein synthesis at least at the same rate as $\mathrm{NO},-\mathrm{N}$ in the nitrate-plant.
\end{abstract}

\section{INTRODUCTION}

Supply of a high level of ammonium nitrogen $(\mathrm{NH},-\mathrm{N})$ generally resulted in restricted growth of many plants as compared to the case with nitrate nitrogen (NO,-N) (Karim and Vlamis, 1962; Harada et al., 1968; Polizotto et al., 1975). There were marked differences between the plants supplied with $\mathrm{NH}_{4}-\mathrm{N}$ and those with $\mathrm{NO},-\mathrm{N}$ in the composition of inorganic and organic constituents (Takahashi, 1961; Harada et al., 1968; Hoff et al., 1974). A concentration of soluble organic nitrogen was higher in the ammonium-fed plants than in the nitrate-fed plants. This fraction of nitrogen compounds was mostly composed of amino acids (Takahashi, 1961; Harada et al., 1968; Hoff et al., 1974; Wilcox et al., 1977). Thus it was postulated that accumulation of soluble organic nitrogen resulted from one, or combination, of the following: a) rapid removal of ammonium, a toxic substance: b) suppressed synthesis of proteins; c) accelerated degradation of proteins. Experiments were conducted in order to compare utilization of inorganic nitrogen for protein synthesis between the ammonium-fed and the nitrate-fed tomato plants. Through roots of tomato plants ${ }^{15} \mathrm{NH}_{4}-\mathrm{N}$ and ${ }^{15} \mathrm{NO}_{3}-\mathrm{N}$ were supplied and incorporation of ${ }^{15} \mathrm{~N}$ into an insoluble nitrogen fraction was examined in this investigation. 


\section{MATERIALS AND METHODS}

Tomato plants (Lycopersicon esculentum Mill., Fukuju No. 2) were grown with $\mathrm{NH},-\mathrm{N}$ and NO,-N (100 ppm N) for 6 days as described elsewhere (Ikeda et al., 1974).

Ammonium and nitrate labelled with ${ }^{15} \mathrm{~N}$ were supplied as follows. The treated plants were exposed to the nutrient solutions containing ${ }^{15} \mathrm{~N}$ (30.0 atom \%) from 10 a.m. to 10 a.m. of the next day (for $24 \mathrm{hr}$ ) and then transferred to the ordinary nutrient solutions which were composed of natural nitrogen. It was a fine day during the experiment. Plants were harvested 24, 31 and 48 $\mathrm{hr}$ after the initiation of application of ${ }^{15} \mathrm{~N}$ and divided into roots, stem, lower (cotyledons and lst-5th leaves), middle (6th-8th leaves) and upper (above 9th leaves) leaves. Each sample was weighed, washed and dried at $90^{\circ} \mathrm{C}$ for $30 \mathrm{~min}$ and subsequently at $70^{\circ} \mathrm{C}$ for $12 \mathrm{hr}$. Dried samples were stored in a desiccator.

Soluble nitrogenous constituents were extracted twice by boiling the powdered sample in $40 \mathrm{~m} l$ of $80 \%$ ethanol. Nitrogen contents of insoluble residues were determined by Kjeldahl method. Most of nitrogen in insoluble residues was considered to be nitrogen from proteins. After the removal of ethanol, the soluble fraction was treated with Devalda alloy and diluted $\mathrm{H}_{2} \mathrm{SO}_{4}$ to reduce $\mathrm{NO}_{3} \cdot \mathrm{N}$, and then digested by Kjeldahl procedure.

The ${ }^{15} \mathrm{~N}$ abundance was assayed by the optical spectroscopic method. Ammonium nitrogen (approx. $100 \mu \mathrm{g}$ ) of the Kjeldahl distillate was oxidized to $\mathrm{N}_{2}$ gas in a discharge tube by Oertli's method (Oertli, 1966). The sample in a discharge tube was excited by a high frequency electrodeless discharge of N-15 analyzer NA-II (Japan Spectroscopic Company, Tokyo). The spectrum was automatically recorded. It was found that the value of atom $\%$ calculated by using the ratio of ${ }^{15} \mathrm{~N}$ to ${ }^{14} \mathrm{~N}$ obtained by the optical method was somewhat larger than that determined by the mass spectrometry. Hence the preparation of a standard curve is required in case of the determination of ${ }^{15} \mathrm{~N}$ abundance by the optical method. Plotting each value of atom $\%$ obtained by using the optical method (X) against that of atom $\%$ excess determined by the mass spectrometry (Y) within the limit of 15 atom $\%$ gave a linear line as shown in Fig. 1. The following equation was derived by the least-squares method.

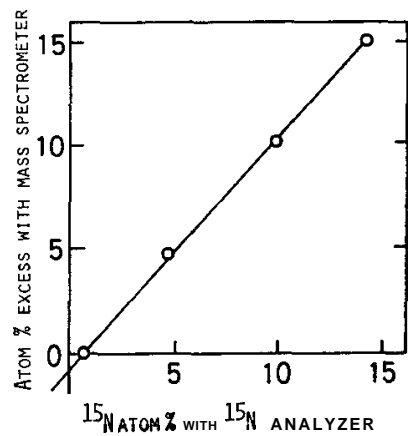

Fig. 1. Standard curve for ${ }^{15} \mathrm{~N}$ determination by the optical method. 
$\mathrm{Y}=1.089 \mathrm{X}-\mathrm{O} .722$

The value of atom $\%$ excess in each sample was re-calculated by use of this equation.

\section{RESULTS}

The growth of the nitrate-plant was superior to that of the ammoniumplant in this experiment. There was no difference in a moisture content between the ammonium-plant and the nitrate-plant. A moisture content of each tissue was larger in the following order; a stem, roots, lower leaves, middle leaves and upper leaves. This order was not varied by nitorgen sources. These facts imply that water metabolism of the ammonium-plant may be yet normal after 7 days' treatment. Table 1 shows total nitrogen and protein nitrogen contents. The total nitrogen content of the ammonium-plant was larger in upper leaves, middle leaves and roots than that of the nitrate-plant, whereas the reverse was true in lower leaves and a stem. Consequently, there were not so large differences in the total nitrogen contents of a shoot and a whole plant between the ammonium-plant and the nitrate-plant.

Table 1. Total nitrogen and insoluble nitrogen contents in individual tissues of the ammonium-plant and the nitrate-plant.

\begin{tabular}{|c|c|c|c|c|c|c|c|c|}
\hline & \multicolumn{4}{|c|}{ Leaves } & \multirow{2}{*}{ Stem } & \multirow{2}{*}{ Top } & \multirow{2}{*}{ Roots } & \multirow{2}{*}{$\begin{array}{l}\text { Whole } \\
\text { Plant }\end{array}$} \\
\hline & upper & middle & lower & whole & & & & \\
\hline & \multicolumn{8}{|c|}{ Ammonium-plant } \\
\hline Total $N(\%)$ & 6.01 & 4. 62 & 3.11 & 4.82 & 2.11 & 4.21 & 4.16 & 4.21 \\
\hline Insoluble $N(\mathscr{S})$ & 4.63 & 3.13 & 2.33 & 3. 49 & 1.20 & 2.98 & 3.27 & 3. 05 \\
\hline Protein $(\%)^{*}$ & 77 & 68 & 75 & 72 & 57 & 71 & 79 & 72 \\
\hline & \multicolumn{8}{|c|}{ Nitrate-plant } \\
\hline Total N $(0)$ & 5. 39 & 4.32 & 3. 26 & 4.57 & 3.65 & 4.17 & 3.50 & 4. 03 \\
\hline Insoluble $\mathrm{N}(\%)$ & 4.00 & 2. $\mathrm{a} 3$ & 2.11 & 3. 18 & 0.92 & 2.60 & 2.38 & 2.55 \\
\hline Protein $(\mathscr{C}) *$ & $7-1$ & 66 & 65 & 70 & 34 & 62 & 68 & 63 \\
\hline
\end{tabular}

$*$ Protein $(\%)=($ Insoluble N/Total N) $\times 100$

It was found that the ammonium-plant had larger insoluble nitrogen contents in all the tissues than did the nitrate-plant. Moreover, a protein content (\% distribution of insoluble nitrogen in total nitrogen) in each tissue of the ammonium-plant was higher than that in a corresponding tissue of the nitrateplant. Above all, with regard to a stem which showed the lowest protein content, $57 \%$ of total nitrogen consisted of protein in the ammonium-plant, while only $34 \%$ in the nitrate-plant. This is due to marked accumulation of NO,-N in a stem of the nitrate-plant.

The changes in atom $\%$ excess of ${ }^{15} \mathrm{~N}$ in soluble nitrogen and insoluble nitrogen of individual tissues are shown in Fig. 2 and 3. At $24 \mathrm{hr}$ (the time when plants were transferred from a solution containing ${ }^{15} \mathrm{~N}$ to that containing natural nitrogen), ${ }^{15} \mathrm{~N}$ abundance of soluble nitrogen was higher than that 


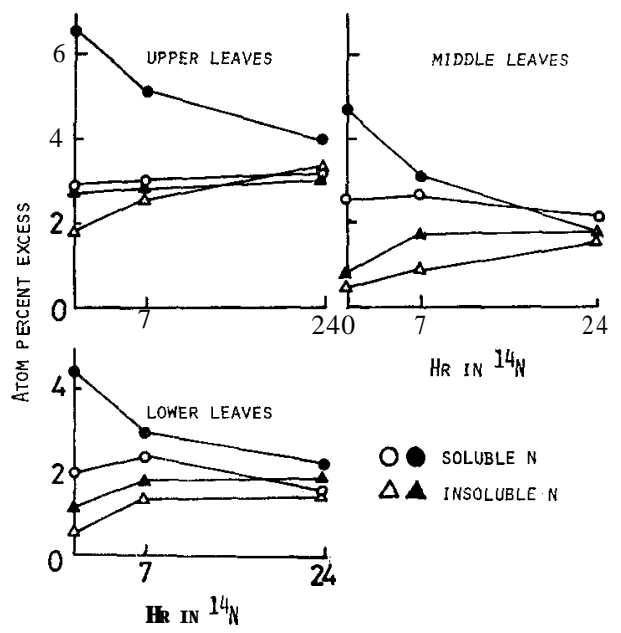

Fig. 2. Change in ${ }^{15} \mathrm{~N}$ abundance in soluble and insoluble fractions of leaf tissues of the ammonium-plant $(O, A)$ and the $\mathbf{n i -}$ trate-plant $(\bullet, \mathrm{A})$.

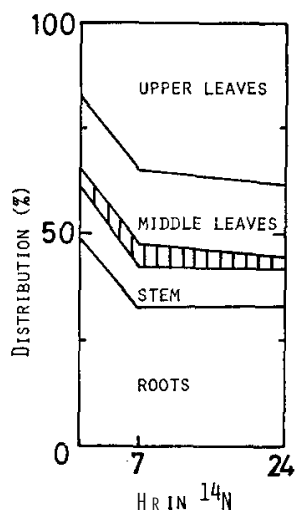

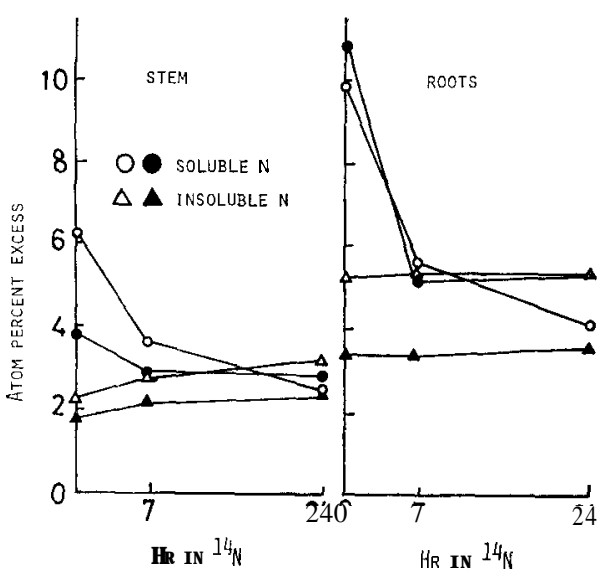

Fig. 3. Change in ${ }^{15} \mathrm{~N}$ abundance in soluble and insoluble fractions of a stem and roots of the ammonium-plant (II, A) and the nitrate-plant $(\mathbf{O})$.

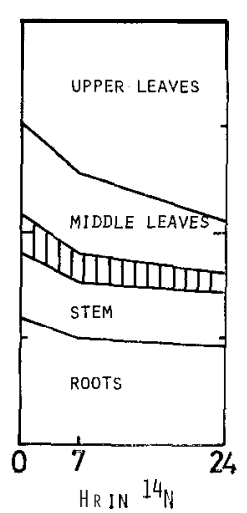

Fig. 4. Percent distribution of newly absorbed nitrogen in individual tissues of the ammonium-plant (left) and nitrate-plant (right). 1.11 , lower leaves.

of insoluble nitrogen but then decreased. On the other hand, that of insoluble nitrogen gradually increased in leaves and a stem but was almost constant in roots regardless of nitrogen sources. Abundance of ${ }^{15} \mathrm{~N}$ in all the leaf tissues of the ammonium-plant seems lower than in those of the nitrate-plant. This indicates that the rate of translocation of newly absorbed nitrogen from roots to leaves was larger in the nitrate-plant than in the ammonium-plant. In other words, $\mathrm{NH}_{4}-\mathrm{N}$ can be rapidly assimilated in roots of the ammonium-plant and the assimilated nitrogen tends to remain there.

The percentage distribution of newly absorbed nitrogen (“" $N$ ) in individual 
tissues is shown in Fig. 4. Just after the cessation of ${ }^{15} \mathrm{~N}$ supply, ${ }^{15} \mathrm{~N}$ was more heavily distributed in the following order: roots, upper leaves, middle leaves, a stem and lower leaves. In the ammonium-plant $50 \%$ of ${ }^{15} \mathrm{~N}$ was present in roots. As described above, it is ascertained that $\mathrm{NH},-\mathrm{N}$ tends to be assimilated and retained in roots. Seven $\mathrm{hr}$ after the transfer to natural nitrogen sources, ${ }^{15} \mathrm{~N}$ in roots decreased and only ${ }^{15} \mathrm{~N}$ in upper leaves increased. Changes in ${ }^{15} \mathrm{~N}$ of other tissues were relatively small. Therefore, in this stage of plant growth, NH,-N and NO,-N absorbed were preferentially transported to upper leaves, i.e. vigorously developing tissues. At $24 \mathrm{hr}$ in ${ }^{14} \mathrm{~N},{ }^{15} \mathrm{~N}$ distribution was similar to that at $7 \mathrm{hr}$ in ${ }^{14} \mathrm{~N}$ in the ammonium-plant. In the nitrate-plant, ${ }^{15} \mathrm{~N}$ in upper leaves continued to increase. Since the nitrate-plant was normally growing and the weight of upper leaves increases, this phenomenon may be observed.

The incorporation of newly absorbed nitrogen $\left({ }^{15} \mathrm{~N}\right)$ into an insoluble fraction (protein) in each tissues is shown in Fig. 5 and 6 . At the initial time, incorporation of ${ }^{15} \mathrm{~N}$ into protein was higher in the following order: upper leaves, roots, lower leaves, middle leaves and a stem. More than $50 \%$ of ${ }^{15} \mathrm{~N}$ translocated was present in protein of upper leaves, indicating that protein is most actively synthesized in the youngest leaves. In middle leaves, incorporation of ${ }^{15} \mathrm{~N}$ into protein was lower than in upper and lower leaves though a considerable amount of ${ }^{15} \mathrm{~N}$ was located in middle leaves (Fig. 4). At present a reason for this finding is not solved.

After labelled nitrogen sources were exchanged for natural ones, incorporation of ${ }^{15} \mathrm{~N}$ into protein increased in the ammonium-plant for $24 \mathrm{hr}$, but that in the nitrate-plant seems to be suppressed during a dark period (7-24 hr), suggesting that most of nitrate may be reduced in green leaves under illumination.

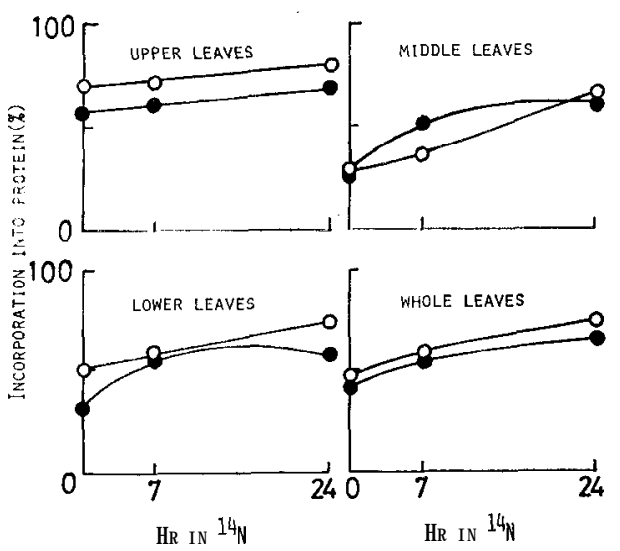

Fig. 5. Incorporation of newly absorbed nitrogen $\left({ }^{15} \mathrm{~N}\right)$ into protein fractions of leaf tissues of the ammonium-plant (O) and the nitrate-plant

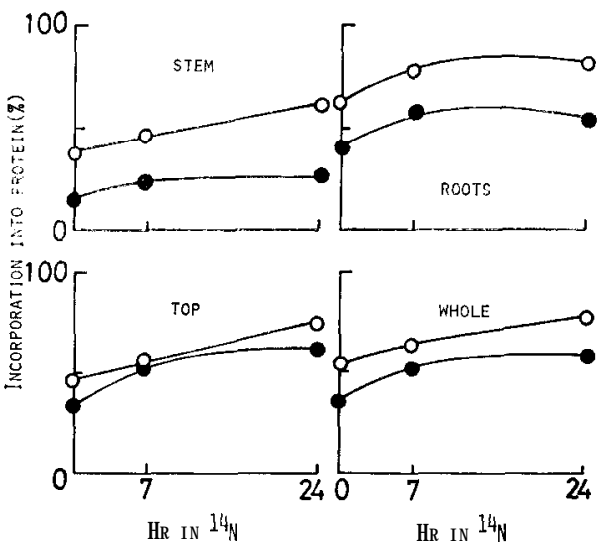

Fig. 6. Incorporation of newly absorbed nitrogen $\left({ }^{15} \mathrm{~N}\right)$ into protein fractions of a stem, roots, a top and a whole plant of the ammonium-plant (O) and the nitrate-plant (e). 
In upper leaves and lower leaves incorporation of ${ }^{15} \mathrm{~N}$ into protein was larger in the ammonium-plant than in the nitrate-plant while in middle leaves there was no clear difference between both the plants. In a stem and roots the proportion of "N-protein was extremely high in the ammonium-plant in comparison with that in the nitrate-plant. Hence, with regard to 'whole plant' $77 \%$ of ${ }^{15} \mathrm{~N}$ absorbed was located in a protein fraction of the ammonium-plant while $59 \%$ of that was found in this fraction of the nitrate-plant.

The proportion of protein ${ }^{15} \mathrm{~N}$ in protein- $\mathrm{N}$ of a whole plant increased as time in natural nitrogen sources and was slightly larger in the ammoniumplant than in the nitrate-plant as shown in Fig. 7. After the cessation of ${ }^{15} \mathrm{~N}$ supply, ${ }^{15} \mathrm{~N}$ in a soluble fraction was incorporated into a protein fraction, so that this proportion is considered to increase as time. A higher rate of incorporation of absorbed ${ }^{15} \mathrm{~N}$ into a protein fraction in the ammonium-plant as shown in Fig. 6 resulted in the difference in this proportion between both the plants.

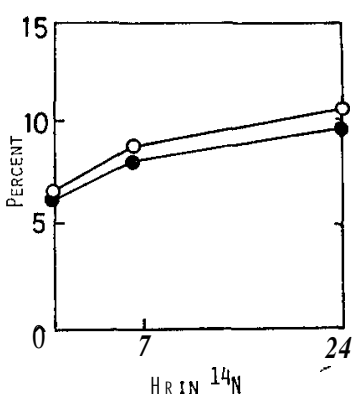

Fig. 7. The rate of newly synthesized protein nitrogen to protein nitrogen in the ammonium-plant (0) and the nitrate-plant (0).

\section{DISCUSSION}

It became clear that sufficient synthesis of protein from inorganic nitrogen was maintained in the ammonium-plant like the nitrate-plant. Especially, the synthesis of protein from inorganic nitrogen was more active in a stem and roots of the ammonium-plant than in corresponding tissues of the nitrateplant. Since ${ }^{15} \mathrm{~N}$ labelled nitrogen passes in roots and a stem earlier in comparison with leaf tissues, a large amount of NO,-N occurs without reduction in these tissues. Ammonium nitrogen is by nature utilized for protein synthesis more rapidly than $\mathrm{NO}_{3}-\mathrm{N}$ because the latter is incorporated into amino acids after the reduction of it whereas the former was used for amino acid synthesis in its original form. Delwiche (1951) has reported that incorporation of ${ }^{15} \mathrm{~N}$ into an insoluble fraction from ${ }^{15} \mathrm{NH}_{4}-\mathrm{N}$ was larger than that from ${ }^{15} \mathrm{NO}_{3}-\mathrm{N}$ in detached tobacco leaves. However, since adequate protein synthesis may continue in order to maintain the normal growth of the nitrate-plant, it is conceived that the rate of incorporation of ${ }^{15} \mathrm{~N}$ into a protein fraction in the nitrate-plant of the present experiment is not exceptional but ordinary. 
Wall (1940) described that the tomato plants supplied with $\mathrm{NH}_{4}-\mathrm{N}$ in sand culture tended to have higher soluble organic nitrogen concentrations and lower protein concentrations than the nitrate-plant, and protein synthesis from $\mathrm{NH}_{4}-\mathrm{N}$ was affected by potassium deficiency. In tobacco plants the ratios of soluble to total nitrogen became larger in $\mathrm{NH}_{4}-\mathrm{N}$ series as temperature declined, indicating that ammonium nutrition caused the inhibition of protein synthesis, while the reverse was true in the nitrate-plant (Fujiwara and Kurosawa, 1957). There are some reports that contents of amino acids and $\mathrm{NH}_{4}$ $\mathrm{N}$ were remakably larger in several plants supplied with $\mathrm{NH},-\mathrm{N}$ than in those with $\mathrm{NO}_{3}-\mathrm{N}$ (Takahashi, 1961; Harada et al., 1968 ; Hoff et al., 1976). The question whether the accumulation of soluble organic nitrogen in the ammonium-plant is due to proteolysis or to de novo synthesis, or to both has not unequivocally been solved. Barker et al. (1966) have found by use of ${ }^{15} \mathrm{~N}$ that ammonium treatment caused a large increase in soluble amino acids at the expense of endogenous sources of nitrogen unless appropriate $\mathrm{pH}$ was kept, indicating considerable degradation of leaf proteins in the ammonium-plant and that accumulation of ${ }^{15} \mathrm{~N}$ in an insoluble fraction was remarkably smaller in leaves of the ammonium-plant without acidity control compared with those of the $\mathrm{CaCO}_{3}$ treated plants. Puritch and Barker (1967) have considered that such disorder of protein metabolism may mainly affect chloroplasts which contain more than $50 \%$ of leaf protein. Unfortunately, however, the authors do not know any study on the comparison of utilization of inorganic nitrogen between the ammonium-plant and the nitrate-plant.

After 6 days' treatment, the amount of nitrogen absorbed per plant slightly reduced in the ammonium-plant in comparison with the nitrate-plant since the growth of the ammonium-plant was restricted. As described above, however, the extent of utilization of absorbed $\mathrm{NH},-\mathrm{N}$ for protein synthesis was equal to or exceeded that of $\mathrm{NO}_{3}-\mathrm{N}$. In the present experiment, the $\mathrm{pH}$ of nutrient solutions were kept above 5.5 as possible during pre-culture, although the $\mathrm{pH}$ in ammonium series declined to 4.5 during ${ }^{15} \mathrm{~N}$-application. Under such good conditions that Barker et al. (1966) recommended, ammonium nutrition is conceivable to fail the inhibition of protein synthesis.

The soluble fraction in this experiment contained both inorganic and organic nitrogen, so that which part of nitrogen absorbed for this period of the treatmant will accumulate in a soluble organic nitrogen fraction remains unknown. The growth of the ammonium-plant began to be inferior to that of the nitrate-plant from this period and chlorosis appeared at the edges of fully expanded leaves of the ammonium-plant, followed by necrosis. Thus the degradation of proteins may be considerably active in such leaves of the ammonium-plant. Although this consideration involves a slight discrepancy, at present there is one explanation, i. e. the ammonium-plant may need active synthesis of protein which exceeds that of the nitrate-plant to repair ammonium injury. Consequently the utilization of inorganic nitrogen newly absorbed was more marked in the ammonium-plant. However, the question whether proteins synthesized in the ammonium-plant are quite similar in their quality to those in the nitrate-plant or not is a matter for future investigation. 


\section{REFERENCES}

Barker, A. V., R. J. Volk and W. A. Jackson 1966 Root environment acidity as a regulatory factor in ammonium assimilation by the bean plants. Plant Physiol., 41: 11931199

Delwiche, C. C. 1951 The assimilation of ammonium and nitrate ions by tobacco plants. J. Biol. Chem., 189: 167-175

Fujiwara, A. and M. Kurosawa 1957 Studies on the biting taste of burley tobacco (nutritional physiology of burley tobacco) (Part 6) Effect of the temperature on the ion absorption and the compostion of the burley tobacco cultured by different forms of nitrogen. J. Sci. Soil Manure, Japan, 28: 91-96

Harada, 'T., H. Takaki and Y. Yamada 1968 Effect of nitrogen sources on the chemical components in young plants. Soil Sci. Plant Nutr., 14: 47-55

Hoff, J. E., G. E. Wilcox and C. M. Jones 1974 The effect of nitrate and ammonium nitrogen on the free amino acid composition of tomato plants and tomato fruits. $J$. Amer. Soc. Hort. Sci., 99: 27-30

Ikeda, M., Y. Yamada and H. Harada 1974 Glucose metabolism in detached leaves of tomato plants grown ammonium and nitrate as nitrogen sources. Soil. Sci. Plant Nutr. $20: 185-194$

Karim, A. Q. M. B. and J. Vlamis 1962 Comparative study of the effects of ammonium and nitrate nitrogen in the nutrition of rice. Plant Soil, 16: 32-41

Oertli, J. J. 1966 Use of optical spectroscopic ${ }^{15} \mathrm{~N}$-analysis to trace a specific nitrogen application in tobacco plants. Plant Soil, 25: 49-64

Polizotto, K. R., G. E. Wilcox and C. M. Jones 1975 Response of growth and mineral composition of potato to nitrate and ammonium nitrogen. J. Amer. Soc. Hort.Sci., $100: 165-168$

Puritch, G. S. and A. V. Barker 1967 Structure and function of tomato leaf chloroplasts during ammonium toxicity. Plant Physiol., 42 : 1229-1238

Takahashi, T. 1961 Studies on the absorption and assimilation of nitrogen by tobacco plant. Bull. Hatano Tobacco Exp. Sta., 50: 1-80

Wall, M. E. 1940 The role of potassium in plants : III. Nitrogen and carbohydrate metabolism in potassium deficient plants supplied with either nitrate or ammonium nitrogen. Soil. Sci., 49: 393-409

Wilcox, G. E., C. A. Mitchell and J. E. Hoff 1977 Influence of nitrogen form on exudation rate, and ammonium, amide, and cation composition of xylem exudate in tomato. J. Amer. Soc. Hort. Sci., 102: $192-196$ 